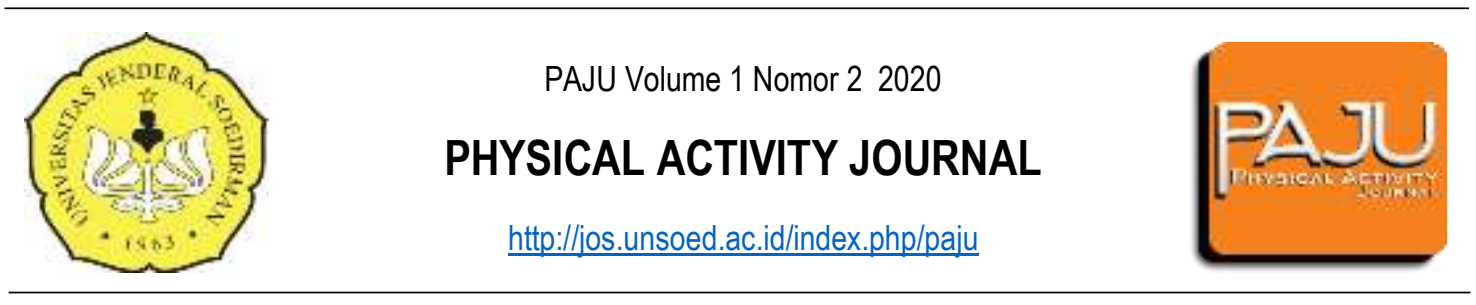

\title{
Hubungan Panjang Tungkai Dengan Kecepatan Lari 60 Meter Siswa Sekolah Dasar
}

\author{
Ahmad Yani' ${ }^{1}$, Rori Hasri² \\ 1,2 Jurusan Pendidikan Jasmani, Kesehatan dan Rekreasi. STKIP Situs Banten, Indonesia \\ email: 1ahmad.yani@stkipsitusbanten.ac.id \\ DOI: https://doi.org/10.20884/1.paju.2020.1.2.2423
}

\begin{abstract}
Abstrak
Kecepatan merupakan faktor penting dalam cabang olahraga atletik, terutama pada nomor lari cepat 60 meter. Tingkat kecepatan lari seseorang dipengaruhi oleh beberapa faktor yang salah satunya yaitu panjang tungkai. Panjang tungkai menjadi salah satu faktor penting dalam kecepatan lari karena dengan semakin panjang langkah maka gerakan kaki akan semakin efisien dan semain cepat. Tujuan penelitian ini yaitu ingin mengetahui hubungan antara panjang tungkai dengan kecepatan lari. Penelitian mengunakan metode korelasional. Populasi dan sampel dalam penelitian ini adalah siswa kelas VI SDN Pangkalan 6 Kecamatan Sobang yang berjumlah 32 orang, pengambilan sampel menggunakan teknik total sampling. Instrumen peneliitan yaitu tes lari 60 meter untuk anak Sekolah Dasar. Hasil penelitian menunjukkan bahwa terdapat hubungan yang signifikan antara panjang tungkai dengan kecepatan lari 60 meter dengan nilai korelasi sebesar 95,5\%, hal ini dibuktikan dengan nilai r-hitung 0,977 dengan probabilitas (Sig.) $0,000<0,05$. Kesimpulan dari penelitian ini yaitu panjang tungkai menjadi salah satu komponen antropometri yang harus diperhatikan dalam lari cepat (sprint), seseorang dengan panjang tungkai yang ideal memberikan kontribusi terhadap kecepatan lari yang baik.
\end{abstract}

Kata kunci: Panjang Tungkai, Kecepatan Lari, Siswa SD

\begin{abstract}
Speed is an important factor in athletics, especially in the 60 meter sprint. The level of a person's running speed is influenced by several factors, one of which is the length of the leg. The length of the tungka is one of the important factors in running speed because the longer the steps the leg movements will be more efficient and faster. The purpose of this study is to find out the relationship between leg length and running speed. Research using the correlational method. The population and sample in this study were 32 students in grade VI of Elementery School Pangkalan 6, Sobang Subdistrict, sampling using a total sampling technique. The research instrument was a 60-meter running test for elementary school children. The results showed that there was a significant relationship between leg length and 60 meters running speed with a correlation value of $95.5 \%$, this was evidenced by the r-count value of 0.977 with a probability (Sig.) Of $0,000<0.05$. The conclusion of this study is that leg length is one of the antropometric components that must be considered in sprinting, a person with an ideal leg length is expected to have a good running speed and must also be supported by appropriate training patterns.
\end{abstract}

Keywords : Leg Length, Running Speed, Elemteray Student 


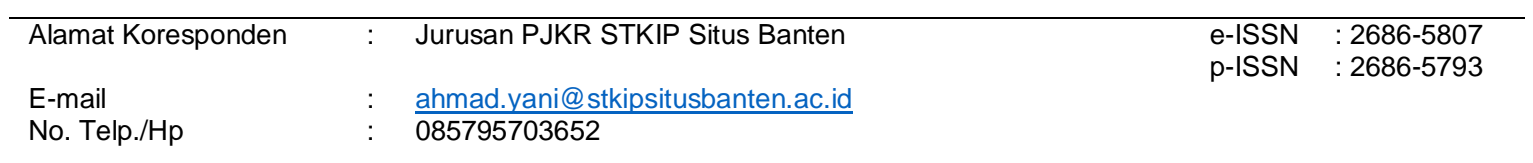

\section{PENDAHULUAN}

Pembelajaran penjas mewajibkan siswa mengikuti berbagai materi olahraga dengan tujuan untuk memfasilitasi siswa mendapatkan berbagai pengalaman gerakan. Budi et al.(2019) menjelaskan bahwa atletik, senam, kebugaran jasmani, kesehatan dan olahraga permainan merupakan materi yang harus diikuti siswa di setiap jenjang pendidikan sekolah. Dengan materi yang beragam, diharapkan siswa mampu tumbuh dan berkembang menjadi mahluk yang sehat jasmani rohani.

Atletik merupakan salah satu materi yang wajib untuk diajarkan kepada siswa disetiap jenjang pendidikan, mulai dari Sekolah Dasar hingga Sekolah Menegah Atas, hal ini dikarenakan atletik merupakan dasar dari semua gerakan olahraga karena mengandung unsur gerakan berjalan, barlari, melompat, dan melempar. Febrianti (2013) menjelaskan sebagian besar cabang olahraga menggunakan gerakan-gerakan seperti cabang olahraga atetik, sehingga atletik sering disebut sebagai induk olahraga atau mother of sport. Lebih lanjut Utami \& Purnomo (2019) Tujuan diajarkannya cabang olahraga atletik yaitu untuk membantu menumbuhkembangkan kemampuan dan keterampilan gerak serta mengenalkan nomor-nomor cabang olahraga atletik kepada siswa.

Salah satu nomor dalam pembelajaran atletik yang diajarkarkan kepada siswa yaitu Lari Cepat atau Sprint. Lari cepat tidak hanya menjadi materi penting dalam pembelajaran, akan tetapi juga menjadi nomor perlombaan yang bergengsi di cabang atletik. Lari cepat atau jarak pendek dapat didefinisikan semua nomor lari yang dilakukan dengan kecepatan penuh (sprint) atau kecepatan maksimal, untuk mencapai jarak yang telah ditentukan (Suhaedi, 2016). Kemudian Handoko (2018) menjelaskan lari sprint adalah lari untuk menempuh jarak tertentu dengan kecepatan maksimal dalam waktu yang sesingkat-singkatnya.

Lari jarak pendek atau sprint dalam perlombaan dibagi menjadi beberapa nomor lari yaitu 100 meter, 200 meter, dan 400 meter. Jadi, komponen utama dari nomor lari jarak pendek yaitu kecepatan maksimal mulai dari awal lari (start) sampai garis akhir (finish). Untuk siswa Sekolah Dasar, jarak lari pendek (sprint) memiliki jarak yang sedikit berbeda dengan siswa SMP maupun SMA. Pada anak Sekolah Dasar, lari jarak pendek di tempuh dengan jarak 60 Meter. Suhaedi (2016) menjelaskan bahwa nomor lari dengan jarak 60 meter yang diajarkan di Sekolah Dasar merupakan hasil pengembangan.

Siswa Sekolah Dasar, dapat melakukan gerakan lari jarak pendek (sprint) dengan baik apabila didukung dengan teknik berlari dan juga faktor kondisi fisik serta struktur antropomerti yang dimiliki oleh siswa tersebut. Faktor antropomerti yang dapat mempengaruhi kecepatan lari diantaranya yaitu tinggi dan berat badan serta panjang pendeknya tungkai yang dimiliki. Hasil penelitian Mustakim (2019) 
menunjukan bahwa Kecepatan maksimal seorang pelari, dipengaruhi oleh panjang tungkai dan berat badan yang dimiliki.

Kecepatan lari seseorang sangat dominan dipengaruhi oleh panjang tungkai yang dimiliki, Jonath (1986) dalam Mustakim (2019) menjelaskan bahwa kecepatan lari adalah hasil kali antara panjang dan frekuensi (jumlah per detik) langkahnya. Oleh karena itu bagi seorang siswa yang ingin memiliki kecepatan yang baik harus juga memiliki panjang tungkai yang ideal sebagai modal utama dari faktor antropomerti bawaan. Hasil penelitian Putri et al. (2019) menunjukan hasil terdapat hubungan atau korelasi kuat yang signifikan antara panjang tungkai dengan kecepatan lari 60 meter.

Berbagai kajian teori dan hasil penenelitian menunjukan bahwa tungkai yang panjang memberikan keuntungan dalam hal kecepatan pada saat berlari, karena dengan tungkai yang panjang maka lankah kaki akan semakin efektif. Akan tetapi ada beberapa temuan bahwa anak dengan tungkai yang pendek juga memiliki keceptan dalam berlari, sehingga sangat menarik untuk mengakaji hubungan antara panjang tungkai dengan kecepatan berlari pada anak.

Identifikasi menganai panjang tungkai yang dimiliki oleh siswa Sekola Dasar, di Provinsi Banten, khusunya di Kecamatan Sobang masih sangat minim di lakukan, hal ini dikarenakan pemilihan atlet atau calon atlet lari masih berdasarkan pengamatan dan pengalaman dari guru di sekolah. Sedangkan untuk pendekatan keilmuan melalui pelasanaan tes dan pengukuran serta penelitian mengenai antropometri panjang tungkai pada siswa belum atau sangat minim dilakukan.

Berdasarkan kajian dari berbagai literatur, hasil penelitian dan kondisi di lapangan maka penting untuk mengkaji lebih mendalam mengenai faktor antropomerti panjang tungkai dalam hubungannya dengan kecepatan lari 60 meter pada siswa Sekolah Dasar, sehingga dapat diketahui apakah panjang tungkai dapat memberikan sumbangan yang efektif dalam kecepatan lari atau ada faktor lain yang berhubungan dengan kecepatan pada usia anak Sekolah Dasar.

\section{METODE}

Jenis penelitian ini menggunakan metode korelasional dengan pendekatan kuantitatif. Fraenkel et al. (2012) menjelaskan bahwa penelitian korelasi merupakan usaha menggambarkan kondisi hubungan antar variabel yang sudah terjadi. Desain korelasional pada penelitian ini digunakan untuk mengetahui tingkat hubungan antara panjang tungkai dengan kecepatan lari 60 meter siswa Sekolah Dasar Negeri Pangkalan 6 Kecamatan Sobang, Banten.

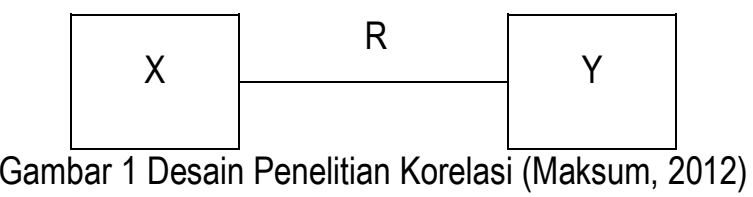




\section{Keterangan :}

$\mathrm{X} \quad=$ variabel bebas (panjang tungkai)

$r \quad=$ korelasi (hubungan)

Y $\quad=$ variabel terikat (kecepatan pada lari cepat 60 meter)

Populasi dan sampel dalam penelitian ini adalah siswa kelas VI SDN Pangkalan 6 Kecamatan Sobang dengan jumlah 32 siswa. Teknik sampling yang digunakan yaitu Toatal Sampling dengan cara mengambil semua anggota populasi menjadi sampel penelitian karena jumlah populasi kurang dari 100. Arikunto (2013) menjelaskan apabila objek kurang dari 100 maka lebih baik diambil semua untuk menjadi sampel penelitian. Instrumen penelitian yang digunakan yaitu tes lari cepat 60 meter untuk siswa Sekolah Dasar (Ismaryati, 2016) dengan validitas 0,98 dan reliabilitas 0,96. Prosedur pelasanaan tes lari cepat dengan jarak 60 meter dilakukan seperti gambar 2 di bawah ini.

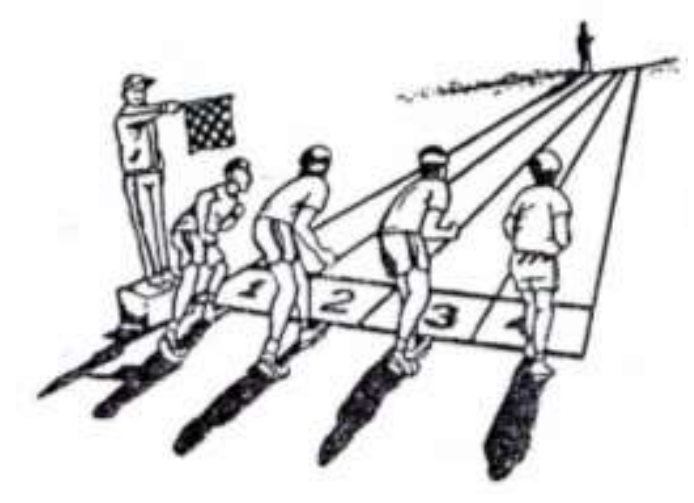

Gambar 2. Tes Lari Cepat 60 Meter

Pelaksanakan tes dilakukan dengan cara, testi berdiri di garis start kemudian setelah mendengar suara "Ya" maka testi berlari sekencang-kencangnya menuju garis finish sepanjang 60 meter dengan tetap berada pada lintasannya masing-masing, kemudian dicatat waktu yang diperoleh oleh testi. Testi melakukan tes lari cepat 60 meter sebanyak dua kali, dengan sebelumnya diberikan waktu istirahat. Waktu yang dicatat yaitu waktu terbaik atau tercepat yang diperoleh oleh testi.

\section{HASIL}

\section{Panjang Tungkai}

Prosedur pengukuran panjang tungkai yaitu dilakukan dari tulang belakang terbawah atau dari trochantor sampai ke lantai bawah dengan posisi sampel yang diukur panjang tungkainya harus dalam posisi berdiri tegak. Hasil perhitungan statistik deskriptif untuk variabel panjang tungkai ditampilkan pada tabel 1 di bawah ini. 
Tabel 1 Statistik Deskriptif Variabel Panjang Tungkai

\begin{tabular}{lll}
\hline No & Statistik Deskriptif & Nilai \\
\hline 1 & Skor minimal & 92 \\
\hline 2 & Skor maksimal & 120 \\
\hline 3 & Rata-rata & 108.81 \\
\hline 4 & Standar deviasi & 8.150 \\
\hline
\end{tabular}

Berdasarkan tabel di atas, secara empirik diketahui data variabel panjang tungkai berada pada rentang 92-120. Rata-rata panjang tungkai yang dimiliki yaitu 108.81 dan standar deviasi 8.150. Selanjutnya data distribusi frekuensi variabel panjang tungkai tertera pada tabel 2 sebagai berikut.

Tabel 2 Distribusi Frekuensi Panjang Tungkai

\begin{tabular}{llll}
\hline No & Interval & \multicolumn{2}{c}{ Frekuensi } \\
\cline { 3 - 4 } & & Absolut & Relatif (\%) \\
\hline 1 & $92-96$ & 2 & 6.2 \\
\hline 2 & $97-101$ & 5 & 15.6 \\
\hline 3 & $102-106$ & 7 & 21.9 \\
\hline 4 & $107-111$ & 5 & 15.6 \\
\hline 5 & $112-116$ & 4 & 12.5 \\
\hline 6 & $117-121$ & 9 & 28.1 \\
\hline & Jumlah & 32 & 100 \\
\hline
\end{tabular}

Berdasarkan hasil analisis deskripsi variabel panjang tungkai dari 32 siswa terdapat 2 orang (6.2\%) memiliki panjang tungkai 92-96 cm, 5 orang (15.6\%) memiliki panjang tungkai $97-101 \mathrm{~cm}, 7$ orang (21.9\%) panjang tungkai $102-106 \mathrm{~cm}, 5$ orang (15.6\%) dengan panjang tungkai $107-111 \mathrm{~cm}$, 4 orang $(12.5 \%)$ panjang tungkai $112-116 \mathrm{~cm}$, dan 9 orang $(28.1 \%)$ memiliki panjang tungkai $117-$ $121 \mathrm{~cm}$.

\section{Kecepatan Lari 60 Meter}

Data kecepatan lari 60 meter diukur dengan menggunakan tes praktek dalam satuan detik yang kemudian hasil tersebut dikonversi menjadi skor baku dengan menggunakan T-skor. Hasil tes kecepatan lari 60 meter pada siswa SD tertera pada tabel 3 di bawah ini.

Tabel 3 Hasil Kecepatan Lari 60 Meter

\begin{tabular}{llc}
\hline No & Statistik Deskriptif & Nilai \\
\hline 1 & Skor minimal & 24 \\
\hline
\end{tabular}




\begin{tabular}{lll}
\hline 2 & Skor maksimal & 62 \\
\hline 3 & Rata-rata & 50.09 \\
\hline 4 & Standar deviasi & 9.871 \\
\hline
\end{tabular}

Berdasarkan tabel di atas, hasil perhitungan statistik deskriptif menunjukkan bahwa skor yang diperoleh variabel kecepatan lari 60 meter pada interval antara 24-62, sehingga diperoleh rentang skor 38 (62-24). Sementara nilai rata-rata 50.09, dan standar deviasi 9.871. Distribusi frekuensi variabel kecepatan lari 60 meter tertera pada tabel 4 berikut ini.

Tabel 4 Distribusi Frekuensi Kecepatan Lari 60 Meter

\begin{tabular}{llll}
\hline & \multirow{2}{*}{ Frekuensi } \\
\cline { 2 - 4 } No & Interval & Absolut & Relatif (\%) \\
\hline 1 & $24-29$ & 2 & 6.2 \\
\hline 2 & $30-35$ & 2 & 6.2 \\
\hline 3 & $36-41$ & 1 & 3.1 \\
\hline 4 & $42-47$ & 6 & 18.8 \\
\hline 5 & $48-53$ & 8 & 25 \\
\hline 6 & $54-59$ & 4 & 12.5 \\
\hline 7 & $60-65$ & 9 & 28.1 \\
\hline & Jumlah & 32 & 100 \\
\hline
\end{tabular}

Hasil analisis deskriptif kecepatan lari 60 meter sebagian besar berada pada kisaran interval $60-65(28.1 \%), \quad 48-53(25 \%), 42-47$ (18.8\%), berikutnya data pada interval 54-59 (12.5\%), 24-29 dan 30-35 masing-masing (6.2\%) dan data terakhir pada interval 36-41 (3.1\%).

\section{Pengujian Hipotesis}

Hipotesis penelitian ini yaitu "Terdapat hubungan antara panjang tungkai dengan kecepatan pada lari cepat 60 meter siswa kelas VI SD Negeri Pangkalan 6 Kecamatan Sobang". Pengujian dilakukan dengan uji analisis korelasi menggunakan program SPSS 21 yang tertera pada tabel 5 berikut ini.

Tabel 5 Analisis Korelasi

\begin{tabular}{llll}
\hline & & Panjang Tungkai & $\begin{array}{l}\text { Kecepatan Lari } \\
60 \text { Meter }\end{array}$ \\
\hline Panjang Tungkai & Pearson Correlation & 1 & $.977^{\text {** }}$ \\
& Sig. (2-tailed) & .000 \\
& $\mathrm{~N}$ & 32 & 32 \\
\hline
\end{tabular}




\begin{tabular}{llll}
\hline Kecepatan Lari 60 Meter & Pearson Correlation & $.977^{* *}$ & 1 \\
& Sig. (2-tailed) & .000 & \\
& $\mathrm{~N}$ & 32 & 32 \\
\hline
\end{tabular}

Berdasarakan tabel 5 diketahui nilai r-hitung 0,977 dengan probabilitas (Sig.) $0,000<0,05$ maka terdapat hubungan antara panjang tungkai dengan kecepatan lari 60 meter siswa kelas VI SD Negeri Pangkalan 6 Kecamatan Sobang. Kemudian untuk mengetahui besar prosentase hubungan kedua variabel tersebut dihitung dengan rumus:

$\mathrm{KD}=\mathrm{r}^{2} \times 100$

$$
\begin{aligned}
& =0,977^{2} \times 100 \\
& =95,5 \%
\end{aligned}
$$

Dari data di atas maka, besarnya hubungan antara panjang tungkai dengan kecepatan lari pendek atau sprint sprint yaitu sebesar $95,5 \%$ dan $4,5 \%$ merupakan faktor lain.

\section{PEMBAHASAN}

Tungkai merupakan bagian tubuh dari manusia yang sangat penting, karena tungka berfungsi untuk menopang berat tubuh selama beraktivitas, khususnya pada saat berolahraga. Isram (2017) menjelaskan tungkai berfungsi sebagai tumpuan pada saat melakukan aktifitas seperti melompat, berjalan, berlari dan sebagainya. Dengan tungkai yang kuat dan terlatih maka seseorang dapat melakukan berbagai gerakan olahraga dengan baik. Hasil penelitian menunjukan habwa setiap peningkatan kekuatan tungkai akan diikuti pula dengan peningkatan kemampuan dalam berolahraga (Zulfikran et al., 2018).

Kecepatan adalah komponen utama dalam nomor lari jarak pendek (sprint), semakin cepat seseorang berlari maka semakin sedikit waktu yang diperlukan untuk mencapai finish. Untuk memperoleh kecepatan yang baik pelu didukung oleh berbagai faktor, salah satunya yaitu panjang tungkai. Nopiyanto et al. (2019) gerakan tungkai merupakan modal utama agar seorang pelari dapat melaju, mulai dari garis keberangkatan hingga garis akhir. Hasil penelitian yang telah dilakukan menunjukan bahwa panjang tungkai berhubungan erat dengan kecepatan lari 60 meter pada siswa SD dengan tingkat hubungan mencapai 95,4 \%. Hal ini mendukung penelitian terdahulu Isram (2017) menunjukan bahwa Power otot tungkai dan panjang tungkai mempunyai hubungan yang signifikan terhadap Kecepatan lari. Lebih lanjut Tisna (2017) untuk antropometri komponen utama pada lari sprint yaitu berat badan, tinggi badan dan panjang tungkai.

Penelitin ini telah mendukung beberapa hasil penelitian dan teori terdahulu, akan tetapi pada hasil penelitian ini memiliki beberapa perbedaan dari penelitian sebelumnya, diantaranya terletak pada 
sampel penelitian yang digunakan yaitu siswa Sekolah Dasar yang belum pernah melakukan latihan kecepatan secara khusus dan terprogram, selain itu juga dilakukan pada siswa kelas VI Sekolah Dasar yang secara anatomis berada pada fase penting dalam pertumbuhan dan perkembangan secara fisik. Murti (2018) menjelaskan karakteristik perkembangan fisik anak usia sekolah dasar difokuskan pada: (1) Tinggi dan berat badan, (2) Proporsi tubuh, dan (3) Otak.

Selain itu, kebaruan dalam penelitian ini yaitu, sampel penelitian tidak dibatasi jenis kelamin melainkan seluruh siswa kelas VI yang terdiri dari siswa laki-laki dan perempuan. Hal ini akan menambah karakterisitik panjang tungkai antara laki-laki dan perempuan. Hasil penelitian Desmita (2009) dalam Murti (2018) mengemukakan bahwa selama masa akhir anak-anak, tinggi bertambah sekitar 5 hingga $6 \%$ dan berat bertambah sekitar 10\% pertahun. Hal ni menunjukan bahwa pola pertumbuhan dan perkembangan fisik antropomertis anak lebih mengarah keberat badan, sedangkan untuk dapat berlari dengan cepat dibutuhkan tubuh yang ideal dengan memperhatikan tinggi badan dan panjang tungkai.

Tinginya hubungan antara panjang tungkai dengan kecepatan lari pada siswa SD pada penelitian ini juga mendukung penelitian terdahulu yang dilakukan oleh Putri et al. (2019) menunjukan hasil terdapat hubungan atau korelasi kuat yang signifikan antara panjang tungkai dengan kecepatan lari 60 meter. Lebih lanjut hasil peneliitan Nopiyanto et al. (2019) menunjukan bahwa siswa memiliki ukuran tungkai yang panjang, akan memberikan kontribusi terhadap kecepatan lari sprint 100 meter dengan baik. Hal itu disebabkan semakin panjang tungkai seseorang akan dikuti dengan jangkauan langkah yang semakin panjang. Berdasarkan hasil penelitian, maka aspek antropometi menjadi faktor yang penting untuk diperhatikan dan dipertimbangkan dalam mengidentifikasi bakat anak di olahraga. Sajoto (1995) dalam Tisna (2017) menjelaskan salah satu aspek biologis yang ikut menentukan pencapaian prestasi dalam olahraga yaitu struktur dan postur tubuh.

Proses identifikasi tingkat kecepatan yang dimiliki oleh siswa Sekolah Dasar dapat dilakukan dengan berbagai macam tes, salah satunya dilakukan pengukuran panjang tungkai yang dimiliki. Apabila pada usia dini sudah memiliki postur panjang tungkai yang ideal, maka dimungkinkan anak tersebut memilki bakat kecepatan yang baik, sehingga dapat dilatih untuk meningkatkan kecepatan serta diarahkan pada cabang olahraga tertentu.

\section{SIMPULAN}

Kecepatan lari memilki hubungan yang signifikan dengan panjang tungkai, tingkat hubungan antara keduanya yaitu sebesar $95,5 \%$, hal ini menunjukan bahwa semakin panjang tungkai yang dimiliki oleh anak maka kecepatan lari juga semakin tinggi, karena berdasarkan kajian ilmu biomekanik semakin panjang tungkai maka akan menyebabkan langkah kaki semakin 
efektif karena jangkauan langkah yang jauh, sehingga frekuensi kaki tidak memerlukan jumlah yang banyak untuk mencapai jarak dengan waktu yang cepat. Selain faktor antropomerti panjang tungkai, teknik berlari juga dapat berpengarauh dalam kecepatan yang dihasilkan sehingga dalam pemilihan atlet berbakat pada nomor lari sprint cabang olahraga atletik harus diperhatikan panjang tungkai serta diberikan program latihan teknik berlari dengan tepat.

\section{REFERENSI}

Arikunto, S. (2013). Prosedur Penelitian: Suatu Pendekatan Praktik (Edisi Revisi). In Jakarta: Rineka Cipta. https://doi.org/10.1017/CBO9781107415324.004

Budi, D. R., Hidayat, R., \& Febriani, A. R. (2019). The Application of Tactical Approaches in Learning Handballs. JUARA : Jurnal Olahraga. https://doi.org/10.33222/juara.v4i2.534

Febrianti. (2013). Pengembangan Materi Atletik Melalui Permainan Atletik Three in One Untuk Ssiswa SD Kelas V. Ournal of Physical Education and Sports, 2(1). https://doi.org/10.15294/jpes.v2i1.1272

Fraenkel, J. R., Wallen, N. E., \& Hyun, H. H. (2012). How to Design and Evaluate Research in Education, 8th Edition (2012). In Climate Change 2013 - The Physical Science Basis.

Handoko, A. H. (2018). Upaya Meningkatkan Hasil Belajar Lari Sprint Melalui Pendekatan Saintifik dan Modifikasi Alat Pada Siswa Kelas X SMA N 1 Kualuh Hulu. Jurnal Penelitian Bidang Pendidikan, 24(1), 38-47.

Ismaryati. (2016). Tes dan Pengukuran Olahraga. Sebelas Maret University Press.

Isram. (2017). Hubungan Power Otot Tungkai Dan Panjang Tungkai Dengan Kecepatan Lari Pada Siswa Putra Kelas VIII SMP Negeri 2 Salawati. Jurnal Pendidikan, 5(1).

Maksum, A. (2012). Metodelogi Penelitian Dalam Olahraga. Unesa University Press.

Murti, T. (2018). Perkembangan Fisik Motorik dan Perseptual Serta Implikasinya pada Pembelajaran di Sekolah Dasar. Wahana Sekolah Dasar. https://doi.org/10.17977/um035v26i12018p021

Mustakim, M. (2019). Hubungan Panjang Tungkai dan Berat Badan Terhadap Kecepatan Lari Sprint 60 Meter. Jurnal IImiah Pendidikan Dasar. https://doi.org/10.30659/pendas.6.1.22-29

Nopiyanto, Y. E., Syafrial, S., \& Sihombing, S. (2019). Hubungan Panjang Tuangkai dan Daya Ledak Otot Tungkai Dengan Hasil Lari Sprint 100 Meter. KINESTETIK. https://doi.org/10.33369/jk.v3i2.9012

Putri, R. F. D., Widodo, S., \& Adji, R. S. (2019). Hubungan Panjang Tungkai Dan Kekuatan Otot Tungkai Dengan Kecepatan Lari 60 Meter (Studi Pada Pemain Sepak Bola Diklat Diponegoro Muda PS UNDIP). Jrnal Kedokteran Diponegoro, 8(1).

Suhaedi, D. (2016). Meningkatkan Hasil Belajar Lari Sprint 60 Meter Melalui Pendekatan Bermain Dengan Alat. JUARA : Jurnal Olahraga. https://doi.org/10.33222/juara.v1i2.20

Tisna, G. D. (2017). Profil Antropomerik, Kekuatan Otot Tungkai, Kecepatan Reaksi, Dan Fleksibilitas Pada Atlet Lari 100 Meter. Jurnal PENJAKORA, 4(2).

Utami, M. S., \& Purnomo, E. (2019). Minat siswa sekolah menengah pertama kelas VIII terhadap pembelajaran atletik. Jurnal Pendidikan Jasmani Indonesia. https://doi.org/10.21831/jpji.v15i1.25486 
Zulfikran, Irfan, \& Fahrizal. (2018). Kontribusi Kecepatan Reaksi Kaki, Kekuatan Tungkaidan Panjang Tungkai Terhadap Kemampuan Lari 60 Meter Pada Murid SD Negeri Sungguminasa IV Kabupaten Gowa. Jurnal, Fakultas Ilmu Keolahragaan, Universitas Negeri Makassar. 